\title{
Effect of Physico- Chemical Properties of Soil on Soil Enzyme L-Asparaginase Activity in Some Soils of Ranga Reddy District Telangana State
}

\author{
J. Aruna Kumari ${ }^{1^{*}}$, P. C. Rao ${ }^{2 *}$, G. Padmaja ${ }^{3^{*}}$ and M. Madhavi ${ }^{4^{*}}$ \\ ${ }^{1}$ Department of Biochemistry, College of Agriculture, Rajendranagar, PJTSAU, India \\ ${ }^{2}$ Dean of Agriculture (Retd) PJTSAU, India \\ ${ }^{3}$ Associate Dean, Agricultural College, Jagital, India \\ ${ }^{4}$ Principal Scientist ACRPP, Weed control, Rajendranagar, India \\ *Corresponding author
}

Keywords

L-asparaginase,

Organic carbon,

Electrical

conductivity,

Texture

Article Info

Accepted:

12 August 2019

Available Online:

10 September 2019
The experiment was to study the distribution of soil enzyme L-asparaginase in the vegetable growing soils of Ranga Reddy district of Telangana state. since usage of herbicides and pesticides has become inevitable in this area, hence a study was conducted to assess the enzyme activities in the soils. For the assay forty soil samples were collected, which were assayed for enzyme activity and they were correlated with the physico chemical properties of soil. The enzyme L- asparaginase activities of the surface soils expressed as $\mu \mathrm{g}$ of $\mathrm{NH}_{4}{ }^{+}$released $\mathrm{g}^{-1}$ soil $\mathrm{h}^{-1}$ ranged from 1.4 to 3.5 with an average value of 1.97 from soils varied in texture from clayey to sandy loam. The $\mathrm{pH}$ ranged from 5.7 to 8.9 , electrical conductivity from 0.1 to $1.23 \mathrm{dSm}^{-1}$ and organic carbon from 0.13 to $1.48 \%$. The available $\mathrm{N}$ varied from 201.5 to $472.5 \mathrm{~kg} \mathrm{ha}^{-1}$. The available $\mathrm{P}_{2} \mathrm{O}_{5}$ status in the soils varied from 11.6 to $79.1 \mathrm{~kg} \mathrm{ha}^{-1}$. The range of available $\mathrm{K}_{2} \mathrm{O}$ ranged from 118 to $411 \mathrm{~kg} \mathrm{ha}^{-1}$. These results showed that soil samples collected exhibited a wide variation in their properties. They are slight acidic to alkaline in reaction and non - saline in nature.

\section{Introduction}

Soil enzymes play an important role in mineralization of nitrogen, phosphorus and sulphur. Mineralization is the process of transformation of organically bound elements into mineral from which is readily taken up by plants and is crucial to plant nutrition. The process of mineralization is brought about by soil microorganisms and also by the abiontic enzymes present in soil. They play an important role in catalyzing several important reactions necessary for the life processes of microorganisms in soils and their by 
stabilizing soil structure, the decomposition of organic wastes, organic matter formation and nutrient cycling (Dick et al., 1994). These enzymes play an important role in agriculture and particularly in nutrient cycling (Tabatabai, 1994 and Dick, 1997). In this regard, all soils contain a varied group of enzymes that determine soil metabolic processes (McLaren, 1975) which, in turn, depend on its physical, chemical, microbiological and biochemical properties. The enzyme levels in soil systems vary in amounts primarily due to the fact, that each soil type has different amounts of organic matter content, composition and activity of its living organisms and intensity of the biological processes. Soil enzyme activities have potential to provide unique interactive biological assessments of soils because of their relationship to soil biology, ease of measurement and rapid response to change in soil management (Dora et al., 2008).

These amino acids are released from the soil organic matter by the activities of enzymes such as arylamidase, and later the "free" amino acids are hydrolyzed by specific enzymes, producing $\mathrm{NH}_{4}^{+}$, which in turn, is nitrified for plant uptake. Among the amidohydrolases, L-asparaginase is one among these enzymes which acts on free amino acids of soils. Nitrogen is an integral part of all proteins, and is one of the main chemical elements required for plant growth and photosynthesis. In most agricultural conditions, availability of usable nitrogen is the most limiting factor for of plant growth. The plant will then utilize nitrogen as a building block to produce proteins in the form of enzymes. Nitrogen is one of the essential element and essential component of purines and pyrimidines of DNA and RNA, enzymes, co-enzymes like NAD, NADP, FAD, cytochromes, vitamins, chlorophyll, intermediates metabolites and some secondary metabolites. At any given time, 95 to 99 percent of the potentially available nitrogen in the soil is in organic forms, either in plant and animal residues, in the relatively stable soil organic matter, or in living soil organisms, mainly microbes such as bacteria. This nitrogen is not directly available to plants, but some can be converted to available forms by microorganisms. A very small amount of organic nitrogen may exist in soluble organic compounds, such as urea, that may be slightly available to plants. Nitrogen controls directly or indirectly the uptake and assimilation of most other nutrients. Hence nitrogen plays a unique role for crop growth and it has to be supplied in adequate amounts in appropriate time for sustainable crop production. L-asparaginase (L-asparagine amidohydrolase EC 3.5.1.1) plays an important role in $\mathrm{N}$ mineralization in soils. The chemical nature of $\mathrm{N}$ in soils is such that a large proportion (15-25\%) of the total soil $\mathrm{N}$ is often released as $\mathrm{NH}_{4}{ }^{+}$by acid hydrolysis (6N HCl). Sowden, (1958) suggested that a portion of the released $\mathrm{NH}_{4}{ }^{+}$comes from the hydrolysis of amide (asparagine and glutamine) residues in soil organic matter. Bremner, (1955) reported that hydrolysis of humic preparation released 7.3 to $12.6 \%$ of total nitrogen in the form of amide nitrogen. Sowden, (1958) also reported that a percentage of the $\mathrm{NH}_{4}{ }^{+}$released during acid hydrolysis was equal to or nearly equal to the sum of nitrogen released from asparatic acid $\mathrm{N}$ plus glutamic acid $-\mathrm{N}$ derived from of asparagine and glutamine. Studies to understand the role of L-asparaginase, in soil $\mathrm{N}$ cycling and the factors (i.e., soil properties, and crop cover and stage of crop, nutrient management practices) that affect the activity of this enzyme will aid in fertility, productivity and sustainability of soils Studies on the distribution of L-asparaginase in soil profile studies reveals that its activity generally decrease with depth which is accompanied by decrease in organic content. Significant relationship between L- 
asparaginase and oranic carbon was observed by Frankenberg and Tabatabai, (1991b) and Raman and Reddy, (1998) for diverse soil types. A strong relationship between soil nitrogen content and the activity of this enzyme is appropriate because of its association with organic matter.

Deng and Tabatabai, (1996) reported that the activities of the amidohydrolases were generally greater in mulch-treated plots than in non-treated plots, because of presence of large number of bacteria, actinomycetes and fungi, which increased 2- to 6-fold as a result of mulching. and were significantly correlated with organic $\mathrm{C}$ contents of soils, with $\mathrm{r}$ values ranging from $(0.70 * * *)$ to $(0.90 * * *)$ Linear regression analyses of enzyme activities on $\mathrm{pH}$ values (in $0.01 \mathrm{M} \mathrm{CaC1}_{2}$ ) of the 28 surface soils showed significant correlations for L-asparaginase, L-glutaminase, and urease, with $\mathrm{r}$ values of $(0.74 * * *),(0.77 * * *)$, and $(0.72 * * *)$, respectively, but not for amidase $(\mathrm{r}=0.24)$.

Frankenberger and Tabatabai (1991 a) reported that the soil properties are related to the amounts of L-glutaminase activity was significantly correlated with the organic C ( $\mathrm{r}$ $=0.79^{*} *$ ). This is because of presence of large amount of microbial biomass on the surface soil and also significantly correlated with total $\mathrm{N}\left(\mathrm{r}=0.76^{* *}\right)$. This is because of the involvement of L- glutaminase in $\mathrm{N}$ mineralisation in soils. They also found that there was no significant relationship between L-glutaminase activity and $\mathrm{pH}$, percentage of clay or sand. There was, however, a significant correlation between L-glutaminase activity and amidase $(\mathrm{r}=0.82 * *)$ Urease $(\mathrm{r}=$ 0.78.') and L-asparaginase $(\mathrm{r}=0.92 * *)$ activities. The activity of arylamidase was significantiy correlated with the activities of L-asparaginase $(\mathrm{r}=0.91 * * *)$, L-aspartase $(\mathrm{r}=$ $0.90 * * *)$, urease $(\mathrm{r}=0.87 * * *)$, L-glutaminase $(\mathrm{r}=0.84 * * *)$ and with amidase $(\mathrm{r}=0.39 *)$ in the 26 surface soils studied.

\section{Materials and methods}

Forty soil samples were collected from different mandals of Ranga Reddy district of southern Telengana zone. These samples were air dried and passed through $2 \mathrm{~mm}$ sieve before use. These soils samples were analyzed for their different soil properties viz. physical, physico-chemical and chemical properties by using standard procedures (Jackson, 1973). Soil $\mathrm{pH}$-The $\mathrm{pH}$ of soil was determined in 1:2.5 soil- water ratio as described by Jackson (1973) using a digital combined glass electrode $\mathrm{pH}$ meter (model DI-707). Electrical Conductivity $\left(\mathrm{dSm}^{-1}\right)$-The EC was determined in 1:2.5 ratio of soil to water extract as detailed by Jackson (1973) using a digital conductivity bridge and expressed in $\mathrm{dSm}^{-1}$ (model DI - 909). Organic Carbon (\%) Organic carbon in soil was estimated by Walkley and Black (1934) method and as described by Jackson (1973). It is expressed as percentage of organic carbon. Mechanical Analysis-Mechanical composition of soils was determined by Bouyoucos hydrometer method (Bouyoucos, 1962). The relative proportion of sand, silt and clay of soils were determined to describe their textural classes were carried out with the help of international triangle (Singh, 1980). Available Nitrogen (kg $\mathrm{ha}^{-1}$ ) -The available nitrogen was determined by Macrokjeldhal distillation method using alkaline potassium permanganate method as described by Subbaiah and Asija, (1956) and modified alkaline $\mathrm{KMnO}_{4}$ method by Sahrawat and Barford and expressed as $\mathrm{kg} \mathrm{ha}^{-}$

1. Available Phosphorus $\left(\mathrm{kg} \mathrm{ha}{ }^{-1}\right)$-The available phosphorus was determined by Olsen's method (1954). The blue colour was developed by using L-ascorbic acid in this method. The intensity of blue colour developed was measured by using spectrophotometer at $620 \mathrm{~nm}$ and expressed as $\mathrm{kg} \mathrm{ha}^{-1}$. Available Potassium $\left(\mathrm{kg} \mathrm{ha}^{-1}\right)$-The available Potassium in soil was estimated by using neutral normal ammonium acetate 
extractant (Jackson, 1967) by using Elico flame photometer and expressed as $\mathrm{kg} \mathrm{ha}^{-1}$.

L-asparagine (extra pure): Substrate for the enzyme L-asparaginase was obtained from M/S SISCO Laboratories. All the chemicals used for analysis were analytically pure chemicals

L-asparagine $(0.125 \mathrm{M})$ : This was obtained by dissolving $18.77 \mathrm{~g}$ of L-asparagine in 1 litre of water THAM buffer $(0.1 \mathrm{M}): 12.28 \mathrm{~g}$ of THAM (Tris hydroxyl methyl amino methane) was dissolved in $800 \mathrm{ml}$ of distilled water and the $\mathrm{pH}$ was adjusted by the addition of $0.1 \mathrm{~N} \mathrm{HCl}$ and $0.1 \mathrm{~N} \mathrm{NaoH}$ to obtain the desired $\mathrm{pH}$, then the volume was made up to 1litre.

Potassium chloride $(2.5 \mathrm{M})+$ Silver Sulphate (100ppm) KCl- $\mathrm{Ag}_{2} \mathrm{SO}_{4}$ solution: $100 \mathrm{mg}$ of $\mathrm{Ag}_{2} \mathrm{SO}_{4}$ was dissolved in $700 \mathrm{ml}$ distilled water to which $300 \mathrm{ml}$ of water containing $186.4 \mathrm{~g}$ of $\mathrm{KCl}$ was added.

Soil sample $(10 \mathrm{~g})$ was taken in a $150 \mathrm{ml}$ conical flask. $12 \mathrm{ml}$ of $0.1 \mathrm{M}$ THAM buffer of desired $\mathrm{pH}$ or distilled water and $8 \mathrm{ml}$ of $0.125 \mathrm{M}$ L-asparagine were added, and then the contents were gently shaken for few seconds and covered with polythene paper. The contents were incubated at $37 \pm 0.5^{\circ} \mathrm{C}$ for 2 hours in BOD incubator. After incubation, reaction was terminated by addition of $50 \mathrm{ml}$ of $\mathrm{KCl}-\mathrm{AgSO}_{4}$ solution. The contents were agitated on mechanical shaker for $30 \mathrm{~min}$ to release all $\mathrm{NH}_{4}{ }^{+}$formed and the suspension was allowed to settle and filtered. The $\mathrm{NH}_{4}{ }^{+}$ released was determined by steam distillation method (Frankenberger \& Tabatabai, 1991b). In the controls the same procedure as described above was followed with the addition of L-asparagine solution after termination of the reaction with $\mathrm{KCl}-\mathrm{AgSO}_{4}$ solution.
MgO: Magnesium oxide was heated in an electrical furnance at $500^{\circ} \mathrm{C}$ for an hour and the powder was collected in dessicator and stored in a tightly stoppered bottle.

4\% Boric acid: $40 \mathrm{gms}$ of Boric acid was dissolved in a beaker containing hot distilled water about $800 \mathrm{ml}$. Then $5 \mathrm{ml}$ bromocresol green and $15 \mathrm{ml}$ of methyl red were added and the volume was made up1 litre with hot distilled water.

$0.005 \mathrm{~N} \mathrm{H}_{2} \mathrm{SO}_{4}$ : This solution was prepared by taking $5 \mathrm{ml}$ of $1 \mathrm{~N} \mathrm{H}_{2} \mathrm{SO}_{4}$ is taken in a 1 litre volumetric flask and make up to the mark by the addition of distilled water.

The activity of L-asparaginase was assayed by Steam distillation method. In this method thirty $\mathrm{ml}$ of the supernatant with $\mathrm{KCl}-\mathrm{AgSO}_{4}$ extract was taken and transferred to Kjeldahl flask. To this a pinch of $\mathrm{MgO}$ was added which was kept at one end of the distillation unit. During steam distillation for $4 \mathrm{~min}$, the solution containing $\mathrm{MgO}$ was heated and the ammonia was released into boric acid containing mixed indicator through a tube dipped in the solution. The ammonia released would change the colour of the solution from pink to pale green at the end of the distillation. This was titrated against standardized $0.005 \mathrm{~N} \mathrm{H}_{2} \mathrm{SO}_{4}$ and the amount released was calculated and expressed as $\mu \mathrm{g}$ of $\mathrm{NH}_{4}{ }^{+}$released $\mathrm{g}^{-1}$ soil $\mathrm{h}^{-1}$. Correlation study was carried out to find the relationship between soil properties and soil enzyme activities.

\section{Results and Discussion}

Forty representative soil samples were collected from different Mandals of Ranga Reddy district of Southern Telengana zone of Telangana state. The results of the analysis of these initial soil samples (Table 4.1) showed that soils varied in texture from clayey to 
sandy loam. The $\mathrm{pH}$ ranged from 5.7 to 8.9 , electrical conductivity from 0.1 to $1.23 \mathrm{dSm}^{-1}$ and organic carbon from 0.13 to $1.48 \%$. The available $\mathrm{N}$ varied from 201.5 to $472.5 \mathrm{~kg}$ ha ${ }^{1}$. The available $\mathrm{P}_{2} \mathrm{O}_{5}$ status in the soils varied from 11.6 to $79.1 \mathrm{~kg} \mathrm{ha}^{-1}$. The range of available $\mathrm{K}_{2} \mathrm{O}$ ranged from 118 to $411 \mathrm{~kg} \mathrm{ha}^{-1}$. These results showed that soil samples collected exhibited a wide variation in their properties. They are slight acidic to alkaline in reaction and non - saline in nature. These results on soil properties represented here are similar to the results obtained by Sireesha, (2008)., Kalyani, (2011)., Vandana, (2012) and Pavani, (2015). L- asparaginaseactivities of the surface soils were analyzed and expressed as $\mu \mathrm{g}$ of $\mathrm{NH}_{4}{ }^{+}$released $\mathrm{g}^{-1}$ soil $\mathrm{h}^{-1}$ ranged from 1.4 to 3.5 with an average value of 1.97 L- asparaginase activity was significantly correlated with organic carbon $(\mathrm{r}$ $\left.=0.984^{* *}\right)$. Significant correlation with soil organic carbon and L-asparaginase with total nitrogen and $(\mathrm{r}=0.54 * *)$

Several properties like organic carbon, total nitrogen, soil $\mathrm{pH}$, clay content moisture content have been shown to influence enzyme activity. The enzyme levels in soil systems vary in amounts primarily due to the fact that each soil type has different amounts of organic matter content, composition, and activity of its living organisms and intensity of biological processes. Enzyme activities of soils are usually correlated either with their organic $\mathrm{C}$ and/or total $\mathrm{N}$ contents. Soil enzymes activities are usually significantly correlated to soil $\mathrm{pH}$ (Gianfred et al., 2005). A strong correlation between the enzyme activity and total number of microorganisms was determined by Cristian and Aurelia, (2010).

Studies on the distribution of L-asparaginase in soil profile studies reveals that its activity generally decrease with depth which is accompanied by decrease in organic content.
Significant relationship between Lasparaginase and oranic carbon was observed by Frankenberg and Tabatabai, (1991b) and Raman and Reddy, (1998) for diverse soil types. A strong relationship between soil nitrogen content and the activity of this enzyme is appropriate because of its association with organic matter

Deng and Tabatabai, (1996) reported that the activities of the amidohydrolases were generally greater in mulch-treated plots than in non-treated plots, because of presence of large number of bacteria, actinomycetes and fungi, which increased 2- to 6-fold as a result of mulching. and were significantly correlated with organic $\mathrm{C}$ contents of soils, with $\mathrm{r}$ values ranging from $\left(0.70^{* * *}\right)$ to $\left(0.90^{* * *}\right)$ Linear regression analyses of enzyme activities on $\mathrm{pH}$ values (in $0.01 \mathrm{M} \mathrm{CaCl}_{2}$ ) of the 28 surface soils showed significant correlations for L-asparaginase, L-glutaminase, and urease, with $\mathrm{r}$ values of $(0.74 * * *),(0.77 * * *)$, and $(0.72 * * *)$, respectively, but not for amidase $(\mathrm{r}=0.24)$.

Frankenberger and Tabatabai (1991 a) reported that the soil properties are related to the amounts of 1-glutaminase activity was significantly correlated with the organic $\mathrm{C}$ ( $\mathrm{r}$ $\left.=0.79^{* *}\right)$. This is because of presence of large amount of microbial biomass on the surface soil, and also significantly correlated with total $\mathrm{N}\left(\mathrm{r}=0.76^{* *}\right)$. This is because of the involvement of $\mathrm{L}-$ glutaminase in $\mathrm{N}$ mineralisation in soils. They also found that there was no significant relationship between L-glutaminase activity and $\mathrm{pH}$, percentage of clay or sand. There was, however, a significant correlation between L-glutaminase activity and amidase $\left(\mathrm{r}=0.82^{* *}\right)$ Urease $(\mathrm{r}=$ 0.78. ${ }^{\circ}$ and L-asparaginase $\left(\mathrm{r}=0.92^{* *}\right)$ activities. The activity of arylamidase was significantiy correlated with the activities of L-asparaginase $(\mathrm{r}=0.91 * * *)$, L-aspartase $(\mathrm{r}=$ $\left.0.90^{* * *}\right)$, urease $\left(\mathrm{r}=0.87^{* * *}\right)$, L-glutaminase 
$\left(\mathrm{r}=0.84^{* * *}\right)$ and with amidase $(\mathrm{r}=0.39 *)$ in the 26 surface soils studied

Miller et al., (1968) found that the Bglucosidase activity decreased by $50 \%$ from 1991to 1993. In contrast, amidase activity increased 1.43-fold over the same period, this amidase activity was associated with the macro- aggregates which in turn increase the soil microbial biomass but $\beta$-glucosidase activity was associated with the fungal growth, which were more in the micro aggregates.

Fig.1 soil enzyme L-asparaginase activity in 40 soil samples

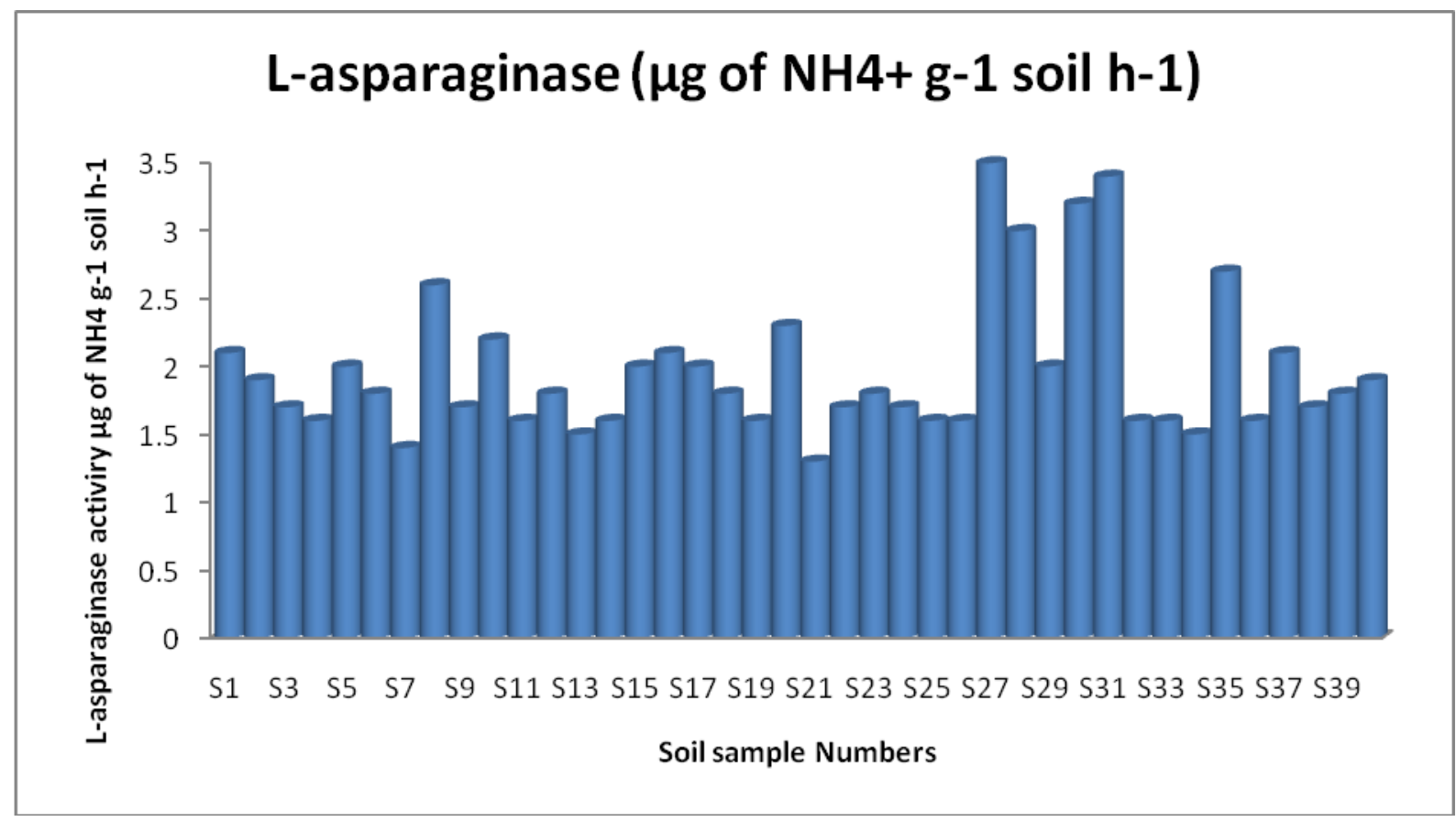

The activity of L-asparaginase was significantly correlated to humus, total $\mathrm{N}$, mineral $\mathrm{N}$, and readily hydrolyzed $\mathrm{N}$ in nonchemozemic soils (Koloskova and Murtazina, 1978). However, Frankenberger and Tabatabai, (1991a) reported a significant correlation between L-asparaginase activity and organic $\mathrm{C}$ and total $\mathrm{N}$, but not with clay content, sand or soil $\mathrm{pH}$ of 26 Iowa soils that they studied. Acosta and Tabatabai, (2001) reported that arylamidase activity was significantly correlated with the content of organic carbon, total $\mathrm{N}$ and clay but not with sand or the $\mathrm{pH}$ of the activity of this enzyme was also significantly correlated with the activities of L-asparaginase, L-asparatase, urease and L-glutaminase. Battacharyya et al., (2007) found that L - asparginase and Lglutaminase activities alone and their ratio with organic-C (ratio index value, RIV), straw and grain yield were higher in well decomposed cow manure (DCM) than municipal solid waste(MSWC) treated soils, due to higher amount of biogenic organic materials like water-soluble organic carbon, carbohydrate and mineralizable nitrogen in the former. The studied parameters were higher when urea was integrated with decomposed cow manure (DCM) or municipal solid waste compost (MSWC), compared to their single applications. Nourbakhshet al., (2002) foubed that 1- 
asparaginase activity was significantly correlated with organic carbon $(\mathrm{r}=0.867 * * *)$, total nitrogrn $(\mathrm{r}=0.784 * * *)$, nitrogen availability $\left(\mathrm{r}=0.816^{* * *}\right)$, where as it was not correlated with sand, silt and clay contents. Lasparaginase activity was negatively correlated with electrical conductivity of saturation paste extracts $(\mathrm{r}=-0.59 * *)$, and sodium adsorption ratio $\left(\mathrm{r}=0.58^{* *}\right)$.

The studies on effect of soil properties on the levels of L- asparaginase activity was significantly correlated with organic carbon $(\mathrm{r}$ $\left.=0.984^{* *}\right)$. Significant correlation with soil organic carbon is a general trend for soil enzymes especially in temperate soils because abiontic enzymes are most probably immobilized on humic organic polymers or entrapped in their polymeric network. In the present study the organic matter is sparingly low and still a significant correlation was observed. It is pertinent that tropical soils contain large quantities of clay and low soil organic carbon and clays are present in the form clay humus complex, significant correlation of L-asparaginase with total nitrogen and ( $\mathrm{r}=0.54 * *)$ available nitrogen points to the fact that considerable portion may be present in the amide form.

\section{References}

Acosta-Martínez V, Tabatabai M.A 2001 Tillage and residue management effects on arylamidase activity in soils. Biology and Fertility of Soils 43: 21-24.

Bremner, J. M. 1951. A review of recent work on soil organic matter. Int. J. Soil Sci. 2: 67-82.

Bremner, J.M., 1955. Studies on soil humic acids: I. The chemical nature of humic nitrogen. J. Agric. Sci. 46, 247-256.

Bouyoucos, G.J. 1962. Hydrometer method improved for making particle size analyses of soils. Agronomy. Journal. 54:464-465.

Cristian, O and Aurelia, O. 2010. Correlation between dehydrogenase activity of Haplicluvisol and total number of microorganisms. Natural Resources and Sustainable Development. 115 - 158.

Deng SP, Tabatabai MA (1996) Effect of tillage and residue management on enzyme activities in soils: I. Aminohydrolases. Biology and Fertility of Soils 22: 202-207

Dick, R.P. 1994. Soil enzyme activities as indicator of soil quality. In J.V. Doran, D.C. Coleman, D.F. Bezdicek and V.A. Stewart (eds.) - Defining Soil Quality for Sustainable Environment, Soil Science Society of America, American Society of Agriculture, Madison. 107 124.

Dick, R.P. 1997. Soil enzyme activities as integrative indicators of soil health. In C.E. Pankhurst, B.M. Doube and V.V.S.R. Gupta (eds.) - Biological Indicators of Soil Health, CAB International, Wellingford. $121-156$

Dora, A.S., Domuta, C., Ciobanu, C and Sandor, M. 2008. Field management effects on soil enzyme activities. Romanian Agricultural Research. 25: 61-68.

Frankenberger, W.T., Tabatabai, M.A., 1991a. Factors affecting L-asparaginase activity in soils. Biology and Fertility of Soils 11, 1- 5.

Frankerberger, W.T., Jr., Tabatabai, M.A., 1991b. L-asparaginase activity of soils. Biology and Fertility of Soils 11, 6-12.

Frankerberger, W.T., Jr., Tabatabai, M.A., 1991c. L-glutaminase activity of soils. Soil Biology and Biochemistry 23, 869874.

Gianfreda, L., Rao, A.M., Piotrowska, A., Palumbo, G and Colombo, C. 2005. Soil enzyme activities as affected by anthropogenic alterations: Intensive agricultural practices and organic pollution. Science of the Total Environment. 341: 265-279. 
Jackson, M.L. 1967. Soil chemical analysis. Prentice Hall of India, New Delhi.

Jackson, M.L. 1973. Soil chemical analysis. Prentice Hall of India Private Limited., New Delhi.

Jordan D., Kremer R.J., Bergfield W.A., Kim K.Y., Cacnio V.N. (1995): Evaluation of microbial methods as potential indicators of soil quality in historical agriculture fields. Biology and Fertility of Soils, 19: 297-302

Mc Laren, A.D and Packer, E. 1970. Some aspects of Enzyme reactions in heterogeneous systems. In R.G. Burns (eds.) - Soil Enzymes, Academic Press Inc, New York.

Miller, R.J., Pinkham, C., Overman, A.R and Dumfor, S.W. 1968. Temperature effects on the acid hydrolysis of glucose - 1 - phosphate and urease hydrolysis of urea. Biochemistry and Biophysics Acta. 167: 607-609.

Koloskova, A. V., and S. G. Murtazina. 1978. Forms of nitrogen and enzyme activity associated with nitrogen metabolism in some tatar soils. Pochvovedenie 5:5864.

Olsen, S.R., Cole, C.V., Watanabe, F.S and Dean, L.A. 1954. Estimation of available phosphorus in soils by extraction with sodium bicarbonate. Circulation from USDA, 939.

Pavani, G. L- glutaminase activity in soils - assay, distribution, kinetics and the effect of crop cover on its activity 2015 M Sc Thesis. Professor Jayashankar Telangan State Agricultural University, Hyderabad

Raman.S and Reddy M.S.R.L 1998 kinetics and activation of L-Asparginase in Alfisols and Vertisols Journal of the Indian society of soil science. 46(3) 367370

Singh, D., Chhonkar, P.K. and Pandey, R.N. 1980. Soil plant water analysis in: $A$ Methods Manual. Indian Agricultural Research Institute, New Delhi.

Sowden, F.J., 1958. The forms of nitrogen in the organic matter of different horizons of soil profiles. Canadian Journal of Soil Science. 38, 147-154.

Subbaiah, B.V and Asija, G.L. 1956. A rapid procedure for the determination of available nitrogen in soils. Current Science. 25: 259-260.

Tabatabai, M.A. 1994. Microbiological and biochemical properties. In R.W. Weaver, J.S. Angle and P.S. Bottomley (eds.) - Methods of Soil Analysis, Part 2, Soil Enzymes, Soil Science Society, Society of America Madison. 775 - 833

Walakley, A and Black, C.A. 1934. Estimation of organic carbon by chromic acid titration method. Soil Science. $\quad 37$ : 29-38.

\section{How to cite this article:}

Aruna Kumari, J., P. C. Rao, G. Padmaja and Madhavi, M. 2019. Effect of Physico- Chemical Properties of Soil on Soil Enzyme L-Asparaginase Activity in Some Soils of Ranga Reddy District Telangana State. Int.J.Curr.Microbiol.App.Sci. 8(09): 799-806. doi: https://doi.org/10.20546/ijcmas.2019.809.095 